University of Nebraska - Lincoln

DigitalCommons@University of Nebraska - Lincoln

October 2007

\title{
Ground Water Dependence of Endangered Ecosystems: Nebraska's Eastern Saline Wetlands
}

\author{
F. Edwin Harvey \\ University of Nebraska - Lincoln, feharvey1@unl.edu \\ Jerry F. Ayers \\ University of Nebraska - Lincoln, jayers1@unl.edu \\ David C. Gosselin \\ University of Nebraska - Lincoln, dgosselin2@unl.edu
}

Follow this and additional works at: https://digitalcommons.unl.edu/natrespapers

Part of the Natural Resources and Conservation Commons

Harvey, F. Edwin; Ayers, Jerry F.; and Gosselin, David C., "Ground Water Dependence of Endangered Ecosystems: Nebraska's Eastern Saline Wetlands" (2007). Papers in Natural Resources. 131.

https://digitalcommons.unl.edu/natrespapers/131

This Article is brought to you for free and open access by the Natural Resources, School of at DigitalCommons@University of Nebraska - Lincoln. It has been accepted for inclusion in Papers in Natural Resources by an authorized administrator of DigitalCommons@University of Nebraska - Lincoln. 
Published in Ground Water 45:6 (2007), pp. 736-752; doi 10.1111/j.1745-6584.2007.00371.x

Copyright @ 2007 F. Edwin Harvey, Jerry F. Ayers, and David C. Gosselin;

journal compilation (C) 2007 National Ground Water Association; published by John Wiley \& Sons Co.

http://www3.interscience.wiley.com/journal/118538742/home Used by permission.

Submitted October 2005; accepted July 2007; published online October 1, 2007.

\title{
Ground Water Dependence of Endangered Ecosystems: Nebraska's Eastern Saline Wetlands
}

\author{
F. Edwin Harvey, Jerry F. Ayers, and David C. Gosselin \\ School of Natural Resources, Hardin Hall, 3310 Holdrege Street, \\ University of Nebraska-Lincoln, Lincoln, NE 68583-0996. \\ Corresponding author - F. E. Harvey, email feharvey1@unl.edu
}

\begin{abstract}
Many endangered or threatened ecosystems depend on ground water for their survival. Nebraska's saline wetlands, home to a number of endangered species, are ecosystems whose development, sustenance, and survival depend on saline ground water discharge at the surface. This study demonstrates that the saline conditions present within the eastern Nebraska saline wetlands result from the upwelling of saline ground water from within the underlying Dakota Aquifer and deeper underlying formations of Pennsylvanian age. Over thousands to tens of thousands of years, saline ground water has migrated over regional scale flowpaths from recharge zones in the west to the present-day discharge zones along the saline streams of Rock, Little Salt, and Salt creeks in Lancaster and Saunders counties. An endangered endemic species of tiger beetle living within the wetlands has evolved under a unique set of hydrologic conditions, is intolerant to recent anthropogenic changes in hydrology and salinity, and is therefore on the brink of extinction. As a result, the fragility of such systems demands an even greater understanding of the interrelationships among geology, hydrology, water chemistry, and biology than in less imperiled systems where adaptation is more likely.

Results further indicate that when dealing with ground water discharge-dependent ecosystems, and particularly those dependent on dissolved constituents as well as the water, wetland management must be expanded outside of the immediate surface location of the visible ecosystem to include areas where recharge and lateral water movement might play a vital role in wetland hydrologic and chemical mixing dynamics.
\end{abstract}

\section{Introduction}

\section{Overview}

Many unique ecosystems are strongly dependent on ground water for their survival (Harvey et al. 2007). This has led researchers to develop the concept of ground water-dependent ecosystems (GDEs) (Hatton and Evans 1998; Eamus and Froend 2006) to help classify and manage such systems. In some rare instances, species contained within these ecosystems may be threatened or endangered (U.S. Fish and Wildlife Service [USFWS] 2007), making the need to understand their dependence on ground water and the hydrologic dynamics of the ecosystem all the more dire.
Examples of such ecosystems and their endemic species include the Edwards Aquifer system, which is home to the fountain darter (Etheostoma fonticola) and Texas wild rice (Zizania texana) (Eckhardt 2006; Longley 2006); the Ozark karst region of northern Arkansas, which sustains the endangered gray bat (Myotis grisescens) and the threatened Ozark cavefish (Amblyopsis rosae) (Nilius and Graening 2000); the Platte River Valley of Nebraska, where increased ground water pumping from the Ogallala Aquifer for irrigation has impacted river levels and the habitat of the pallid sturgeon (Scaphirhynchus albus), whooping crane (Grus americana), and interior least tern (Sterna antillarum athalassos) (National Research Council 2005); the springs of Rock Creek Park, District of Co- 


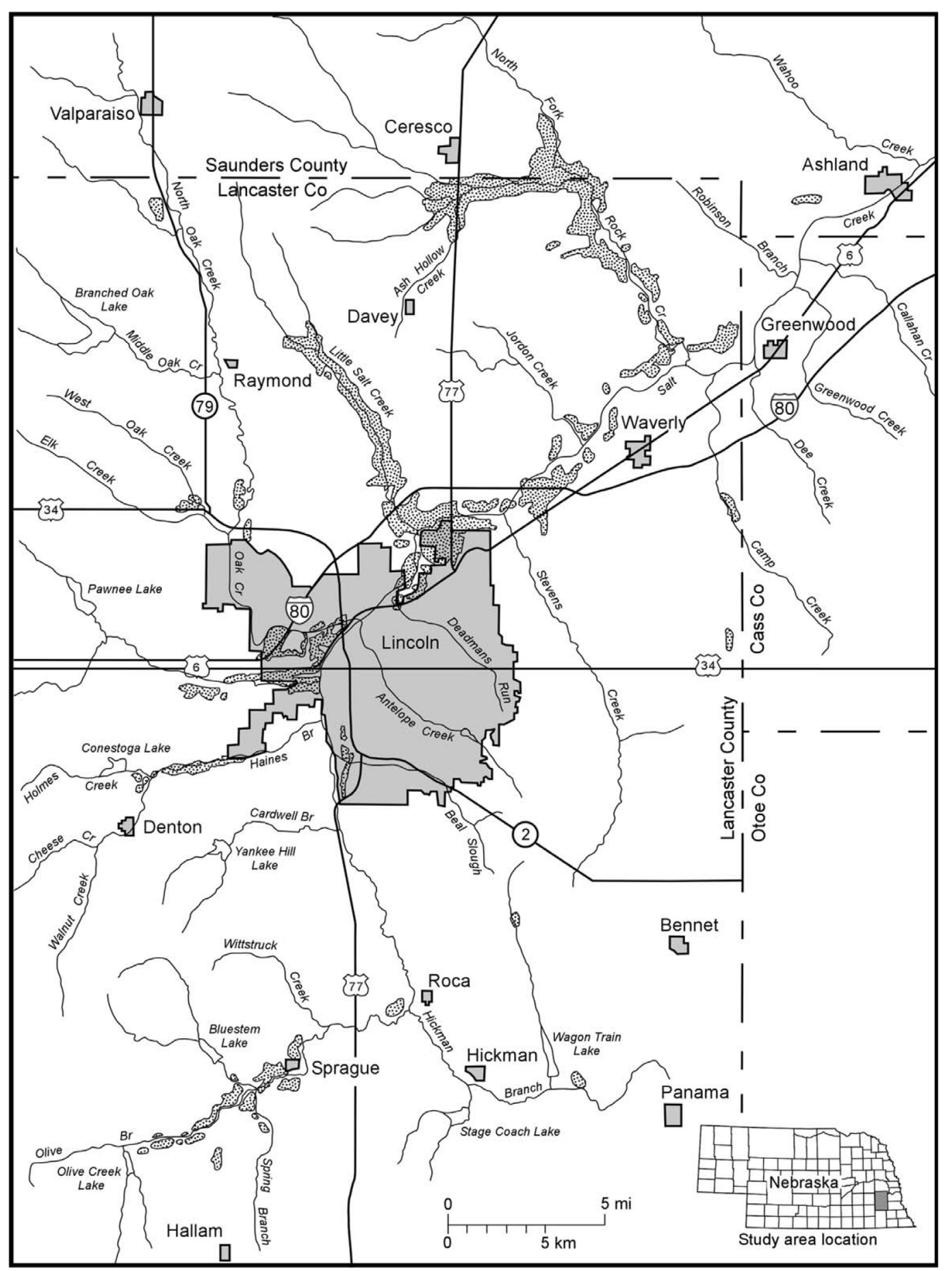

Figure 1. Eastern Nebraska saline wetland locations map (modified from Farrar and Gersib 1991). The stippled area represents locations classified as saline wetlands based on soil or plant characteristics.

lumbia which sustain the Hay's Spring amphipod (Stygobromus hayi) (Pavek 2002); and the limestone substrate of the Guánica Commonwealth Forest in Puerto Rico, where the troglobitic ground water shrimp (Typhlatya monae) are found in the ground water of three caves (U.S. Fish and Wildlife Service [USFWS] 2006).

Another example of this type of GDE is eastern Nebraska's endangered saline wetlands. These wetlands occur in and around the capital city of Lincoln (Figure 1) and con- tain some of the most limited and endangered vegetation communities in the state (Kaul 1975). As Lincoln has grown in recent decades, continued encroachment of urban areas, increased pollution levels from the use of herbicides, pesticides, and other chemicals, and stream channelization of feeder creeks and streams that while affording flood control has lowered the water table beneath the wetlands, have led to these wetlands being classified as critically imperiled (Clausen et al. 1989). 
Saline wetland ecosystems occur in a variety of hydrological settings worldwide (Mitsch and Gosselink 2000; Shaw and Fredine 1956). Most are commonly found in coastal areas (estuarine wetlands) where tidal transport of sea water delivers dissolved salts to the wetlands (Jagtap et al. 2002; Pennings et al. 2005). Saline wetlands also exist in arid climates or in isolated basins where evaporation of fresher surface water within the wetland concentrates dissolved salts (Smith 2003; Brock and Shiel 1983). Saline wetlands may also exist in ground water discharge zones where saline water is transported to streams and lakes on the surface under artesian conditions (Sánchez Navarro et al. 2001; Strobel and Gerla 1993).

Nebraska's saline wetlands are ground water discharge wetlands occurring in a small region of the eastern portion of the state within the regional discharge zone of the Great Plains (Dakota) Aquifer System. These wetlands are located within the flood plains of the Salt, Little Salt, and Rock Creek watersheds in Lancaster and southern Saunders counties (Figure 1) and provide habitat for a variety of salt-tolerant plant species such as inland saltgrass (Distichlis spicata), sea blite (Suaeda depressa), and saltwort (Salicornia rubra). Saltwort is listed as one of Nebraska's endangered species. In addition to these unique plant species, the saline wetlands are also home to a rare and restricted endemic subspecies of the tiger beetle (Cicindela nevadica var. lincolniana), which is listed as an endangered species both by Nebraska and federally by the U.S. Fish and Wildlife Service (Department of the Interior-Fish and Wildlife Service 2005).

As with all wetlands, local and regional surface and ground water exchanges play a vital role in maintaining and sustaining the ecosystem by controlling the availability and flow of water (Hayashi and Rosenberry 2002). Additionally, in the case of Nebraska's saline wetlands, the hydrology also controls the transport and distribution of the salts that produce the necessary saline conditions. Thus, their very existence and survival would not be possible without ground water. To date, however, the hydrogeology and water chemistry of these rare Nebraska wetlands have not been studied in great detail, and thus little is known about the connections between these surface ecosystems and the underlying ground water and dissolved salts. Likewise, little is known about the extent of the flow systems that feed the wetlands, and thus the possible need to apply current protections to upland areas outside and surrounding the alluvial valleys where the wetlands occur. Without this crucial knowledge, it is difficult to make informed management decisions about wetland protection or preservation or to assess the impact of future urban expansion and development.

\section{Previous studies}

The saline wetlands near Lincoln were first described by Hayden (1872) in his report on a geological reconnaissance of the state, but the discussion was brief and did not provide hydrologic details related to the wetlands. Shirk (1924) studied the vegetation within these inland saline areas and examined near surface climate, hydrology, and soil chemistry. Ungar et al. (1969) describe the halophytes present in the wetlands and discuss the impacts of salinity levels on species germination, growth, and areal distribution (see discussion following). Joeckel and Clement (1999) discuss salt basin surface features and salt crust mineralogy and provide a brief history and overview of all previous work. A short Nebraska Game and Parks Commission (NGPC) publication written for the general public entitled Nebraska Salt Marshes: Last of the Least (Farrar and Gersib 1991) provides a brief history of the region related to the salt basins and a very basic overview of the ecology, hydrology, and geology of the wetlands. Finally, a report by Rus et al. (2003) described streambed adjustments and channel widening in eastern Nebraska, and discusses installation of a number of grade-control structures to prevent channel incision into the Salt Creek Basin saline wetlands near Lincoln.

Early conceptual models, derived mostly from visual observations at wetland sites, suggested that the wetlands were created by the lateral movement of saline water from seeps in eroded low-lying areas where alluvial fill intersected outcrops of the underlying sandstone bedrock of the Dakota Formation (Hayden 1872). In 1996, a cooperative, multidisciplinary river basin study coordinated by U.S. Department of Agriculture (USDA [1996]) was carried out at a saline wetland site along Rock Creek (north of Lincoln). As part of that study, researchers installed several shallow polyvinyl chloride (PVC) pipes and recorded about 6 to 10 water level readings on average at each site from May 1994 through November 1994. Their observations showed decreasing water levels closer to the incised channel of Rock Creek, though water table slopes were not as steep as was expected, and they noted a connection between water level fluctuations and high precipitation events during the late summer. In addition to these conclusions, the study also suggested that the saline water was actually upwelling as discharge from a regional ground water flow system within the bedrock, and it further surmised that the salts were not discharging directly from the sandstone of the Dakota Formation, but were likely migrating upward from deeper underlying bedrock units, though no specific source was identified.

While the preliminary USDA (1996) study provided the first real insights into saline wetland hydrology, the lack of continuous, long-term water level monitoring data and a complete assessment of water chemistry and age limited researchers from making conclusions related to seasonal or regional ground water dynamics and/or salt transport. As such, it was the USDA study's recommendation that additional research would be needed to (1) quantify surface water hydrology and the long-term impact of channelization and subsequent erosional down cutting on water table position; (2) define the extent of the hydraulic connection between the wetlands and the deeper saline water source; (3) determine if the saline wetlands were dependent more on modern recharge, or older, artesian discharge, or some mixture of both; and finally (4) identify and locate the subsurface salt source.

\section{Purpose}

If present and future management, restoration, protection, and conservation practices with regard to these endangered wetlands and reintroduction of the Salt Creek tiger 
beetle are to be effective, the long-term dynamics of the relationship between surface water and ground water within the wetlands, and the transport dynamics of the dissolved salts within the bedrock and overlying unconsolidated deposits, must be more clearly understood. Therefore, this study's overall purpose is to better understand the connections and interactions between ground water and the saline wetland ecosystem. Specific research questions to be answered are (1) what are the daily, monthly, and yearly ground water hydroperiods of the wetlands; (2) what is the nature and mechanism of saline ground water-fresh surface water mixing within the saline wetlands; (3) what is the chemical composition of ground water from within the deep bedrock and shallow overburden aquifers, and what is the salinity source; and (4) what are the ground water residence times within each aquifer?

Locally, the results of this work will provide wetland managers with the data necessary to make more responsi- ble and effective decisions regarding wetland preservation, restoration, and management related to endangered species protection and reintroduction. More generally speaking, the results will demonstrate the importance of extending ground water-fed wetland management strategies to areas beyond the water's (or ecosystem's) edge to account for the impact of regional flow systems and upland recharge zones and not just the discharge zone locations of the ecosystems themselves.

\section{Study area}

\section{Site selection}

Two easily accessible sites, viewed to be representative of saline wetland ecosystems across the area, were selected for this study. The Rock Creek (RC) site near Ceresco, Nebraska (Figure 2) and at the easternmost edge of the Jack
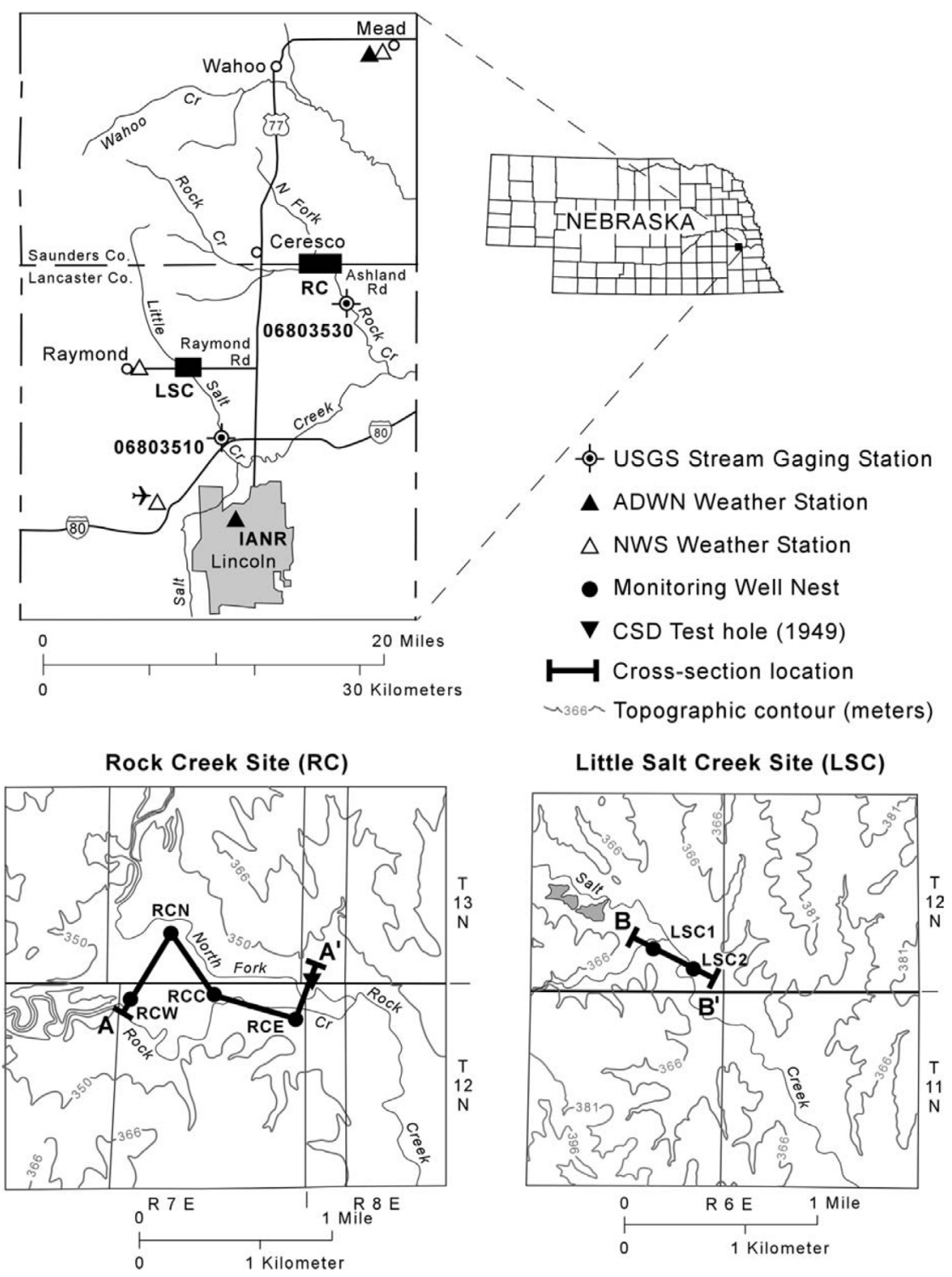

Figure 2. Location of the LSC and RC study sites. Also shown are the locations of nearby weather stations, stream gages, and a deep geologic test hole drilled by the Nebraska Conservation and Survey Division. 
Sinn Wildlife Management Area ( http://lancaster.ne.gov/ city/parks/admin/wetlands/localwet.htm ) is owned and managed by the NGPC. This site was used in a previous reconnaissance study (USDA 1996; Ayers 1995) and as such, six monitoring wells were already present at the site. During the years of this study, the NGPC constructed a berm around the northernmost portion of the wetland and installed three large weirs at the easternmost end of the property to control bank erosion and prevent stream water levels across the site from lowering further. The weirs raised water levels only about 1 foot, due to concerns of flooding the property of upstream landowners. Prior to weir installation, down cutting was as deep as $2.7 \mathrm{~m}$ in some areas (T. LaGrange, personal communication, Lincoln, Nebraska, 2007).

The Little Salt Creek (LSC) site near Raymond, Nebraska (Figure 2) is part of The Nature Conservancy's Little Salt Fork Marsh and serves as a mitigation bank for the Burlington Northern Santa Fe Railroad ( http://www.nature.org/ wherewework/northamerica/states/nebraska/preserves/ art290.html ). This site underwent restoration in the years preceding this study whereby berms and control structures were installed and native saline vegetation was reintroduced (Burlington Northern Railroad Company 1997).

\section{Saline wetland ecohydrology}

Eastern Nebraska saline wetland plant ecology has been described by Shirk (1924); Ungar et al. (1969); and Farrar and Gersib (1991). A brief educational summary is presented here as plant species distribution is a function of hydrology; and whereas ground water is the source and transport medium of the saline water that sustains the wetlands, it is important to understand the relationship between plant ecology and hydrology if these wetlands are to be properly restored, managed, and preserved.

The most important factors affecting salt-tolerant plant distribution are soil saturation and soil solution salt con- centrations (Shirk 1924; Ungar et al. 1969; Farrar and Gersib 1991), both of which are in a constant state of flux beneath Nebraska's saline wetland communities. This makes it difficult to differentiate spatial and temporal boundaries separating wetland plant communities; however, Farrar and Gersib (1991) suggest a simplified conceptual ecohydrologic model for plant species distribution (Figure 3). Wetland basins are subdivided from their centers to their margins into aquatic communities, salt flats, and transition zones. These areas are in turn located between prairie communities and adjacent to the local creek or stream (Figure 3) that flows through the wetland. Aquatic communities thrive in and near open water and include such species as sago pondweed (Potamogeton pectinatus) and prairie bulrush (Scirpus maritimus var. paludosus). The salinity of this surface water is quite variable, ranging from fresh (recent precipitation) to highly saline in composition (especially during times of extensive evaporation).

Surrounding these open water areas are broad salt flats where the wetland's most interesting and often most endangered species grow, including sea blite (Suaeda depressa) and saltwort (Salicornia ruba). Note that eastern Nebraska's saline wetlands mark the southernmost extension of saltwort in the prairie region (Ungar et al. 1969). Here, soils are extremely saline (Ungar et al. 1969) and halite and thenardite salt crusts form as a result of capillary wicking of ground water (Joeckel and Clement 1999).

The greatest diversity of plant species in the saline wetlands is found in the transition zones between the salt flats and the surrounding prairie. Here, such species as saltmarsh aster (Aster subulatus), foxtail barley (Hordeum jubatum), and spearscale (Atriplex subspicata) thrive. Soils in this zone are saturated or are inundated frequently for too short a duration to develop the soil salinity necessary for halophytes tolerant of highly saline soils (Farrar and Gersib 1991).

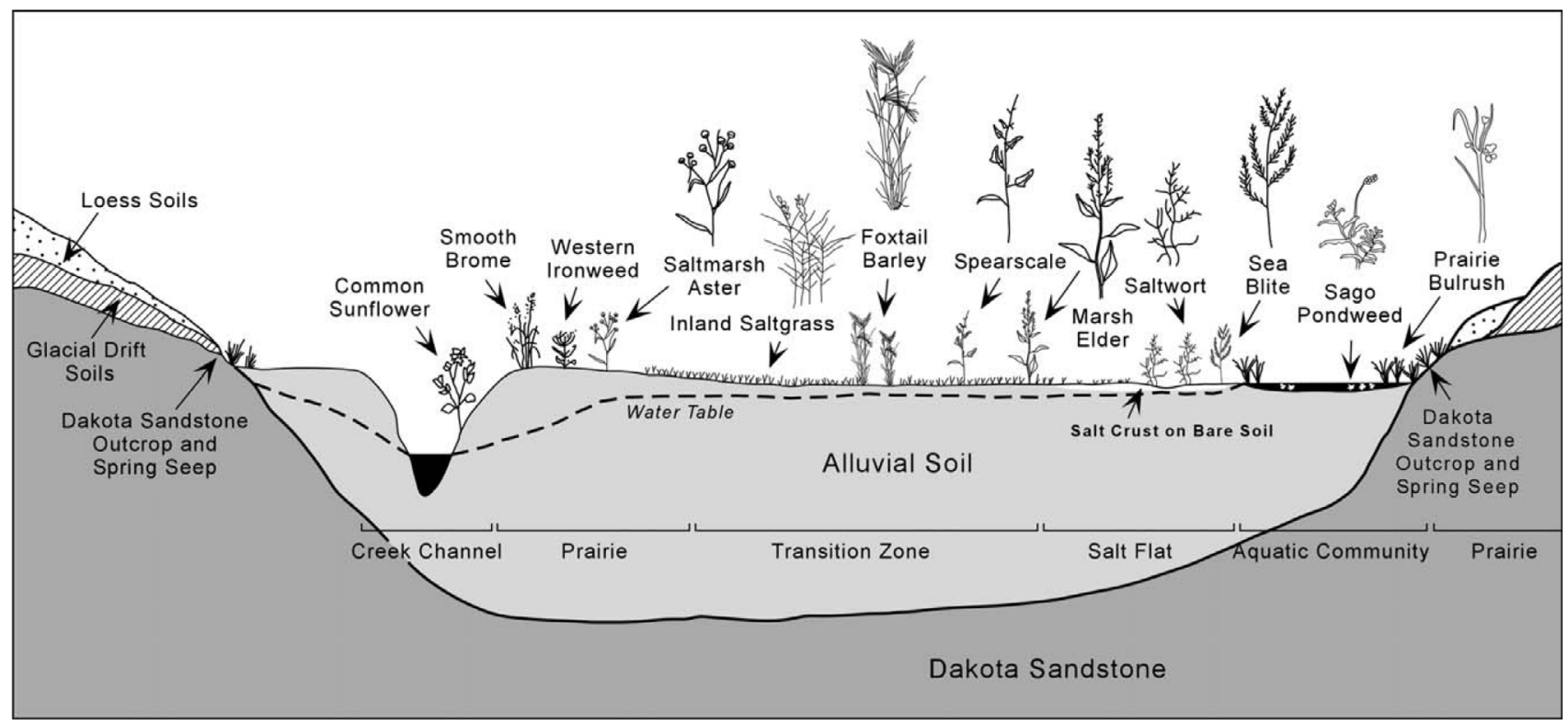

Figure 3. A diagrammatic representation of plant species distribution across the saline wetlands (modified from Farrar and Gersib 1991). 

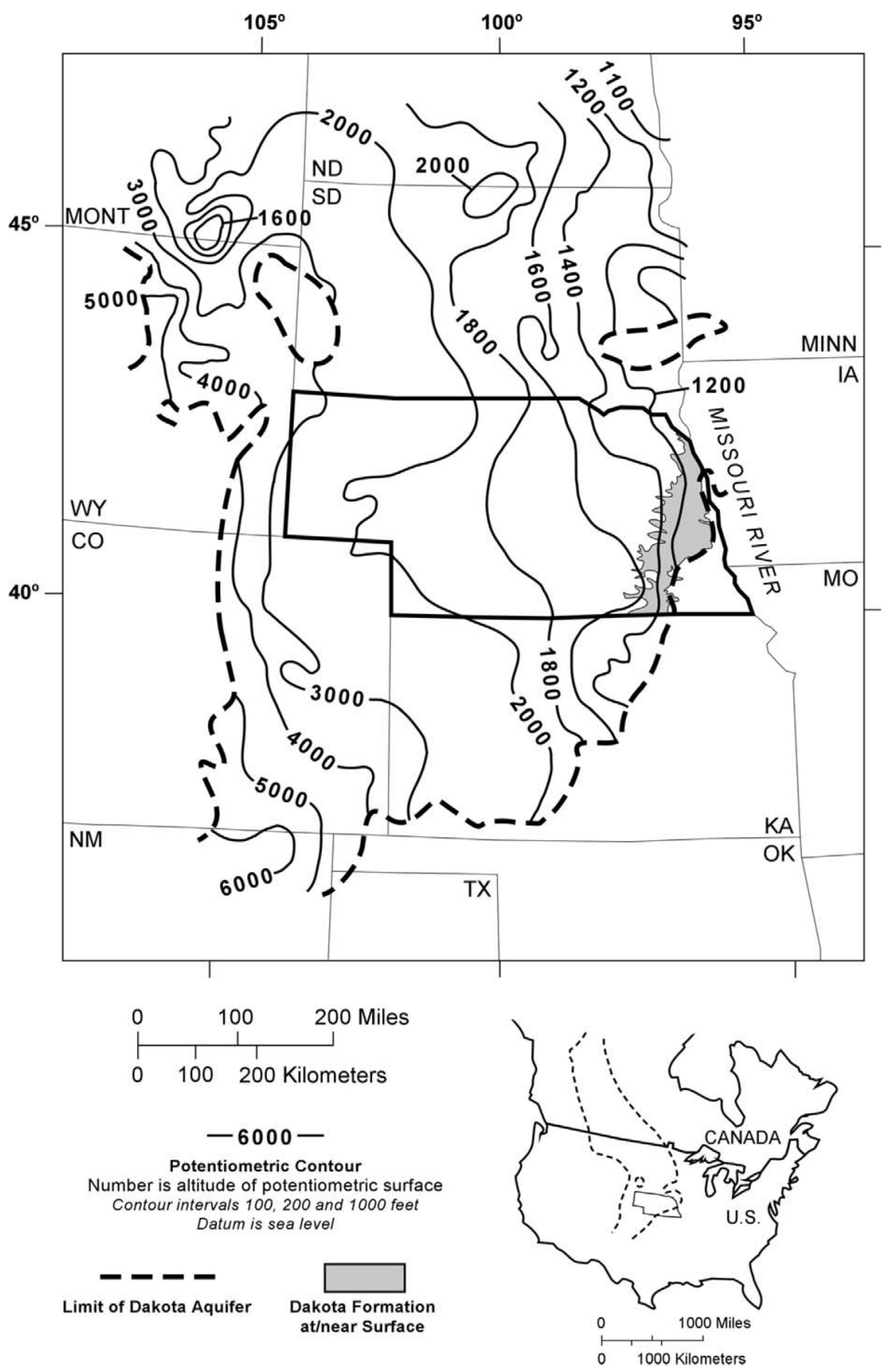

Figure 4. Recent regional potentiometric surface and extent of the Dakota (Great Plains) Aquifer in Nebraska. The North American extent of the aquifer is shown in the lower right corner. Modified from Leonard et al. (1984).

Plant distribution also suggests the existence of different important hydrologic processes across the wetland as well. Where highly saline ground water discharges undiluted to the surface, only the most salt-tolerant plants would be expected to thrive. This might also be true in areas where ponded water is being evaporated and the dissolved salt load concentrated. In areas where ground water discharge is diluted by precipitation or flooding, lower salinities would give rise to different plant communities. Finally, where surface water is not derived from underlying saline ground water but rather is derived from precipitation or fresh wa- ter runoff from the surrounding uplands, saline plant communities would not be observed.

\section{Saline wetland geology}

Nebraska's eastern saline wetlands are fed by ground water discharge from the Dakota Formation (Aquifer) which is part of the Great Plains Aquifer System (GPAS). The GPAS is one of the most extensive aquifers in North America, extending from the Arctic Circle in Canada to New Mexico (Figure 4) (Gosselin et al. 2001; Helgeson et al. 
1984, 1982; Jorgensen et al. 1993; and http://capp.water. usgs.gov/gwa/ch d/D-text4.html for a comprehensive discussion of the geology, hydrology, and geochemistry of the GPAS). The Dakota Formation contains a highly variable series of sandstones and shales that reflect a complex pattern of deposition and erosion associated with alluvial, deltaic, and shoreline sedimentary environments along the eastern margin of the Cretaceous Western Interior Seaway.

Witzke and Ludvigson (1994) have defined a general sequence for the Dakota Formation that includes a lower sandstone-dominated Nishnabotna Member and an upper mudstone-dominated Woodbury Member with sandstone channel bodies. In east-central Nebraska, especially between Omaha and Lincoln, most relevant to this study, the Woodbury Member is not recognizable, and the continuous sheetlike sandstone bodies of the Nishnabotna Member are the primary hydrostratigraphic unit. In Nebraska, the thickness of the Nishnabotna sandstones is not well constrained but likely varies in thickness from 50 to $75 \mathrm{~m}$ across the region. Veatch (1969) indicated that the sandstone bodies are geometrically complex and discontinuously interbedded with shales.

Across east-central Nebraska, the Dakota Formation occurs in the subcrop and is overlain in some locations by a thin layer of Pre-Illinoian glacial till typically mantled with thicker sequences of Loveland (140,000 to 135,000 years before present [ybp]), Gilman Canyon (40,000 to 24,000 ybp), and/or Peoria loess (23,000 to 13,000 ybp) (Maher et al. 2003).

As a result of the down cutting by streams in eastern $\mathrm{Ne}-$ braska, outliers of the Dakota exist that are as large as 130 $\mathrm{km}^{2}\left(50 \mathrm{mi}^{2}\right)$ in areal extent. Such outcrops of the Dakota occur in a few locations in the Lincoln-Omaha area.

From northern Burt and Cumming counties and south into the middle of Lancaster (the location of the study sites) and southern Seward counties, the Dakota overlies Pennsylvanian rocks (Maher et al. 2003). The Pennsylvanian rocks consist of alternating units of marine limestones and shales. Southward into Kansas, the Dakota rests on Permian sedimentary rocks. The Permian rocks in southeastern Nebraska are predominantly limestones and shales. However, younger Permian strata in the Southwest also contain red beds and salt deposits.

On a regional scale, hydraulic head in the Dakota decreases progressively from west to east (Helgeson et al. 1984) (Figure 4). In areas where Quaternary units overly the Dakota Formation, stratigraphic variability can produce either confined or unconfined ground water conditions within the Dakota Aquifer.

\section{Methodology}

\section{Monitoring well installation}

At the LSC site, two well nests were installed (four wells at LSC1 and two wells at LSC2). To augment the existing well nests (RCE, RCC, RCW), at the RC site an additional nest of three wells was installed (RCN). Wells were installed using mud rotary or auger methods depending on the depth of the well (varying from 3.8 to $60 \mathrm{~m}$ ), and con- structed of 2-inch schedule 40 PVC pipe, fitted with 2- and 5-foot-slotted PVC screens at the LSC site and RC sites, respectively. Screen slot width was 0.010 inches. Within each hole, gravel pack was placed vertically across the screen interval to a height of approximately $1 \mathrm{~m}$ above the top of the screen. The gravel pack was capped with approximately $0.5 \mathrm{~m}$ of bentonite hole plug, and the hole was sealed with grout to the surface. During drilling of the deepest hole at each nest, drill-cutting samples were collected every 5 feet and were used to produce a lithologic log for the hole.

\section{Ground water level monitoring}

Ground water levels within eight of the wells were monitored every $3 \mathrm{~h}$ for 2 years using Solinst ${ }^{\circledR}$ Level Logger downhole transducers. Measured water levels were corrected for barometric pressure using an additional Level Logger installed in the overlying air column of one shallow well at each site.

\section{Chemical and isotope sampling}

Ground water samples were collected once from selected monitoring wells at both sites for major ion and isotope analyses. Prior to sampling, wells were purged for 15 min or until water temperature remained constant. Ground water samples were collected using a 2-inch submersible Grundfos ${ }^{\circledR}$ pump. Collected water samples were passed through a $0.45-\mu \mathrm{m}$ filter and collected in 30-mL Nalgene ${ }^{\circledR}$ plastic bottles. One of the bottles was designated for anion analysis and one for cation analysis. The cation bottle was acidified to a $\mathrm{pH}$ less than 4 with a small volume of nitric acid $\left(\mathrm{HNO}_{3}\right)$. In addition to the samples for major ion analysis, several additional 125-mL samples were collected from each well for stable isotope, tritium, and carbon-14 analysis. All bottles were stored and transported at $4^{\circ} \mathrm{C}$.

\section{Chemical and isotope analysis}

Temperature, conductivity, and $\mathrm{pH}$ values were measured in the field using Orion ${ }^{\circledR}$ meters and probes with accuracies of $\pm 0.1^{\circ} \mathrm{C}, \pm 10 \mu \mathrm{S} / \mathrm{cm}$, and $\pm 0.05 \mathrm{pH}$ units, respectively. Field alkalinity was determined using a $\mathrm{HACH}^{\circledR}$ digital titrator. Inorganic chemical analyses were carried out at the University of Nebraska-Lincoln Soil and Plant Analytical and Groundwater Chemistry Laboratories. Anion analysis was performed using ion chromatography. Cation and trace metal analysis were carried out using atomic absorption spectrometry. Alkalinity as bicarbonate $\left(\mathrm{HCO}_{3}\right)$ was also determined in the lab by volumetric titration. With the exception of strontium, the stable isotope analyses were performed at the Environmental Isotope Laboratory at the University of Waterloo in Waterloo, Ontario, Canada. Stable oxygen, hydrogen, and carbon in dissolved inorganic carbon (DIC) determinations were made using a mass spectrometer following the procedures of Epstein and Mayeda (1953), Coleman et al. (1982), and Gupta and Polach (1985), respectively. Oxygen, hydrogen, and carbon results are reported as parts per thousand (\%o) with respect to VSMOW, VSMOW, and VPDB, respectively using the $(\delta)$ notation where, $\delta_{\text {sample }}=\left(R_{\text {sample }} / R_{\text {reference }}-1\right) \times 1000$. $R_{\text {sample }}$ is the ra- 
tio of ${ }^{18} \mathrm{O} /{ }^{16} \mathrm{O},{ }^{2} \mathrm{H} /{ }^{1} \mathrm{H}$, and ${ }^{13} \mathrm{C} /{ }^{12} \mathrm{C}$ in the sample and $\mathrm{R}_{\text {stan- }}$ dard is the ratio of the international standard. The analytical precisions for $\delta^{18} \mathrm{O}, \delta^{2} \mathrm{H}$, and $\delta^{13} \mathrm{C}$ are $0.2,2.0$, and $0.2 \%$, respectively.

Strontium isotope analyses were completed by Dr. Carol D. Frost of the Department of Geology and Geophysics at the University of Wyoming. Strontium was isolated using Sr-spec resin and measured on a mass spectrometer. An average ${ }^{87} \mathrm{Sr} /{ }^{86} \mathrm{Sr}$ ratio of $0.710250 \pm 0.00001(2 \sigma)$ and a normalized ${ }^{88} \mathrm{Sr} /{ }^{86} \mathrm{Sr}=0.1194$ were measured for the NBS 987 Sr standard. ${ }^{87} \mathrm{Sr} /{ }^{86} \mathrm{Sr}$ values are measured routinely at the $2 \sigma$ level to $\pm 0.001 \%$ or better.

Tritium concentration was determined by the electrolytic enrichment method of Taylor (1977), with a lower detection limit of 0.8 tritium units (TU). Tritium is reported in $\mathrm{TU}$, where $1 \mathrm{TU}$ is the ratio of 1 atom of tritium $\left({ }^{3} \mathrm{H}\right)$ to $10^{18}$ atoms of protium $\left({ }^{1} \mathrm{H}\right)$.

Carbon-14 ages were determined using accelerator mass spectrometry at the Rafter Radiocarbon Laboratory of the Institute of Geological and Nuclear Sciences in New Zealand. The ${ }^{14} \mathrm{C}$ content is corrected for the $\delta^{13} \mathrm{C}$ value and reported according to the conventions of Stuiver and Polach (1977). Carbon-14 values are reported as percent modern carbon (PMC). Radiocarbon dates are based on 95\% activity of NBS oxalic acid as modern standard, normalized for $\delta^{13} \mathrm{C}$ equal to $-19.0 \%$ PDB, according to Craig (1961). Carbon-14 ages in ybp were estimated using the decay equation corrected for dilution using the $\delta^{13} \mathrm{C}$ correction model (Pearson 1965; Pearson and Hanshaw 1970).

\section{Precipitation and stream discharge data}

Daily precipitation data were compiled for the study period (2000 to 2002) from two Automated Weather Data Network (AWDN) stations that are operated by the University of Nebraska-Lincoln's High Plains Climate Center ( http:// www.hprcc.unl.edu ). The two stations were located at Mead, Nebraska, approximately $20 \mathrm{~km}$ northeast of the RC site, and in Lincoln (IANR site) about $15 \mathrm{~km}$ southeast of the LSC site (Figure 2).

Yearly precipitation averages from 1995 to 2002 were obtained from the Mead and Lincoln AWDN sites, and from three additional National Weather Service sites-one in Mead (Mead 6 S), one near the town of Raymond (Raymond 2 NE), and one near the Lincoln Municipal Airport at the western edge of the city (Figure 2).

Daily stream discharge data were obtained for 2000 to 2002 from the USGS Surface-Water for the Nation database ( http://waterdata.usgs.gov/nwis/sw ) for RC and LSC, at the gauging stations closest to the study sites (Figure 2).

\section{Results}

\section{Long-term precipitation patterns}

In order to evaluate the connections between ground water and longer term saline wetland ecosystem health, there needs to be some confidence that the ground water levels recorded during the study period are representative of periods of normal rainfall across the region and not some anom- alously dry or wet period in the region. One way to validate conclusions derived from short-term hydrologic observations is to examine precipitation patterns across the region and in the vicinity of the wetlands relative to prior years. Average annual precipitation data from stations in the region surrounding the saline wetlands are plotted, along with the minimum and maximum rainfalls, and the range of 30-year normal values for the stations, in Figure 5.

Rainfall across the region has been quite variable from 1995 through 2002. Precipitation amounts were lower than the 30-year normals during 2000, at or above normal during 2001, and at or below normal in 2002. This suggests that hydrologic observations made during the first and second years of the study should be interpreted with caution as the data may have been impacted by local drought conditions. Observations in year 2 may be more representative of wetter or normal years but may also reflect a period of recovery for the previous year's shortfall of rainfall. Conclusions drawn during this study are therefore most representative of slight drought conditions and are likely not as representative of more normal precipitation conditions.

\section{Site geology}

Within the uplands of both the RC and LSC watersheds, local surficial materials consist of wind-deposited loess, glacially derived tills, and alluvial terrace and channel deposits. Geologic well logs and drill cuttings were used at each of the two sites to construct more specific geologic crosssections of the underlying aquifer materials (Figure 6). Alluvium overlies the Dakota Formation at each site, which is sequentially underlain by gray limestone of Pennsylvanian age - the upper Shawnee Group at the RC site and the middle Wabaunsee Group at the LSC site (M. Joeckel, Lincoln, Nebraska, 2007, personal communication). The Dakota Formation contains alternating layers of sandstone, siltstone, and clay and locally contains hard ironstone and/or chert bands. In some areas, a thick gray clay/shale layer is present at depth which may act as an aquitard.

\section{Water levels and hydraulic gradients}

Two-year continuous water level monitoring results of the eight wells fitted with transducers were converted to ground water elevation above sea level (hydraulic head) and are presented in Figure 7.

In saline environments, when comparing hydraulic head values between water of differing densities, it is sometimes necessary to correct water levels by computing the equivalent fresh water head for each well (Cooper et al. 1964) prior to calculating hydraulic gradients or determining ground water flow direction. Fresh water head is computed using the equation $l_{\mathrm{f}}=\left(\rho_{\mathrm{s}} / \rho_{f}\right) l_{\mathrm{s}^{\prime}}$, where $l$ is the measured length of the water column above the casing terminus, $\rho$ is the density of the water in the casing, and the subscripts $s$ and $f$ refer to saline and fresh, respectively (Cooper et al. 1964). Due to the similarities in the total dissolved solids (TDS) and thus salinity values of well water at the RC site (Table 1), it was not necessary to compute a fresh water head value. At the LSC site, however, the extreme salinity differences between 


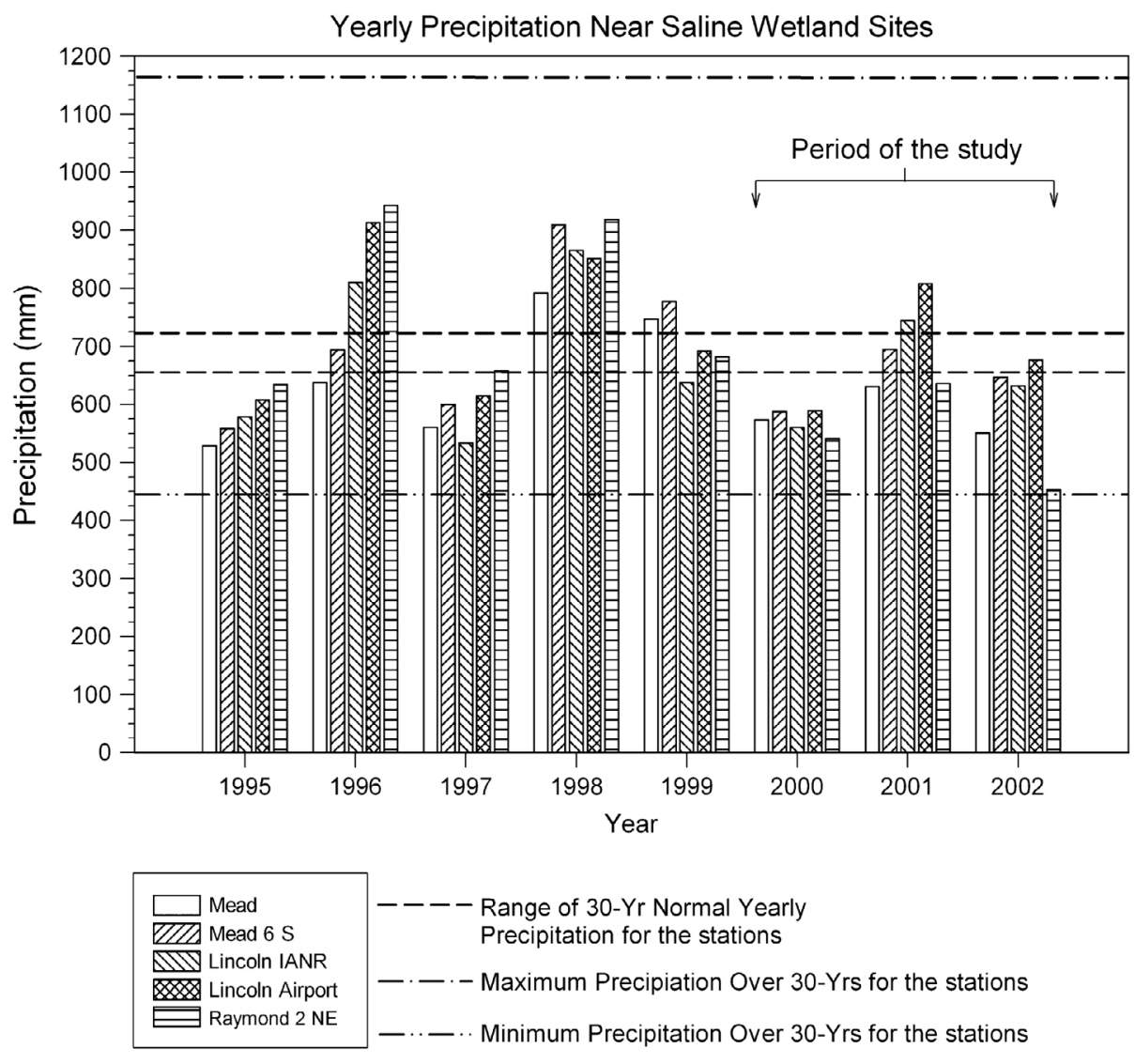

Figure 5. Yearly precipitation data for the region from 1995 through 2002. The 30-year normal precipitation for the region is also shown. Data was taken from weather stations in Mead, Raymond, and Lincoln, Nebraska (High Plains Climate Center, UNL).

the shallow fresh water well (LSC1-B) and the deeper saline well (LSC1-D) indicate that a correction might be necessary. Unfortunately, as the wells were sampled only once for chemical analysis, only one density could be computed, and furthermore, there was no available information on how density changed within the well daily or seasonally, if at all. If the density of the saline water sampled from well LSC1$\mathrm{D}\left(\rho_{\mathrm{s}}=1012 \mathrm{~g} / \mathrm{cm}^{3}\right)$ is used to correct the head value recorded by the transducer on the day of chemical sampling, it results in an increase in the head of the deeper well of approximately $0.7 \mathrm{~m}$ over the measured value. Since there was only one density value, and since the equivalent fresh water head resulted in a larger gradient, and no change in the direction (upward) of ground water flow between the two wells, this correction was not applied to the remaining head values or subsequent hydraulic gradient calculations at the RC site.

The hydrographs in Figure 7 show a clear seasonal trend in ground water levels in each of the wells. They rise from October through June and decline during the summer months (July to September). Superimposed on this seasonal variability are several short-term ground water level rises during the summer months that correspond to large precipitation events that result in increased stream discharges. Ground water levels may rise over a meter during these storm events. Water levels in each of the shallowest wells at each site intersected the ground surface during the study period and were typically 1 to $2 \mathrm{~m}$ below ground surface. Ground water levels in the deeper wells are typically at or above the ground surface, suggesting artesian conditions in the deeper portions of the aquifer.

Comparison of water levels between the 2 years shows a slight decline in the regional water table. This is likely a consequence of drought conditions that were present in eastern Nebraska during 2000 and 2002 (Figure 5), but this supposition cannot be verified without water level data from years when the aquifer received more normal precipitation amounts.

Comparison of water levels measured during this study (2000 to 2002) with water levels measured during the 1996 USDA study (USDA 1996) shows that ground water levels were higher in 1996, with water often at the surface of the alluvium. Comparison of precipitation data indicates that 1996 was wetter than the present monitoring period with annual rainfall greater than 30 -year average amounts (Figure 5).

Using the continuous hydraulic head data collected from the shallowest and the deepest observation well at each well nest site, the uncorrected vertical hydraulic gradient was computed for the site (Figure 7). For this study, upward hydraulic gradients are defined as positive (ground water flow is upward) and downward hydraulic gradients as negative (ground water flow downward). With the exception of well nest RCE, ground water flow was upward throughout 


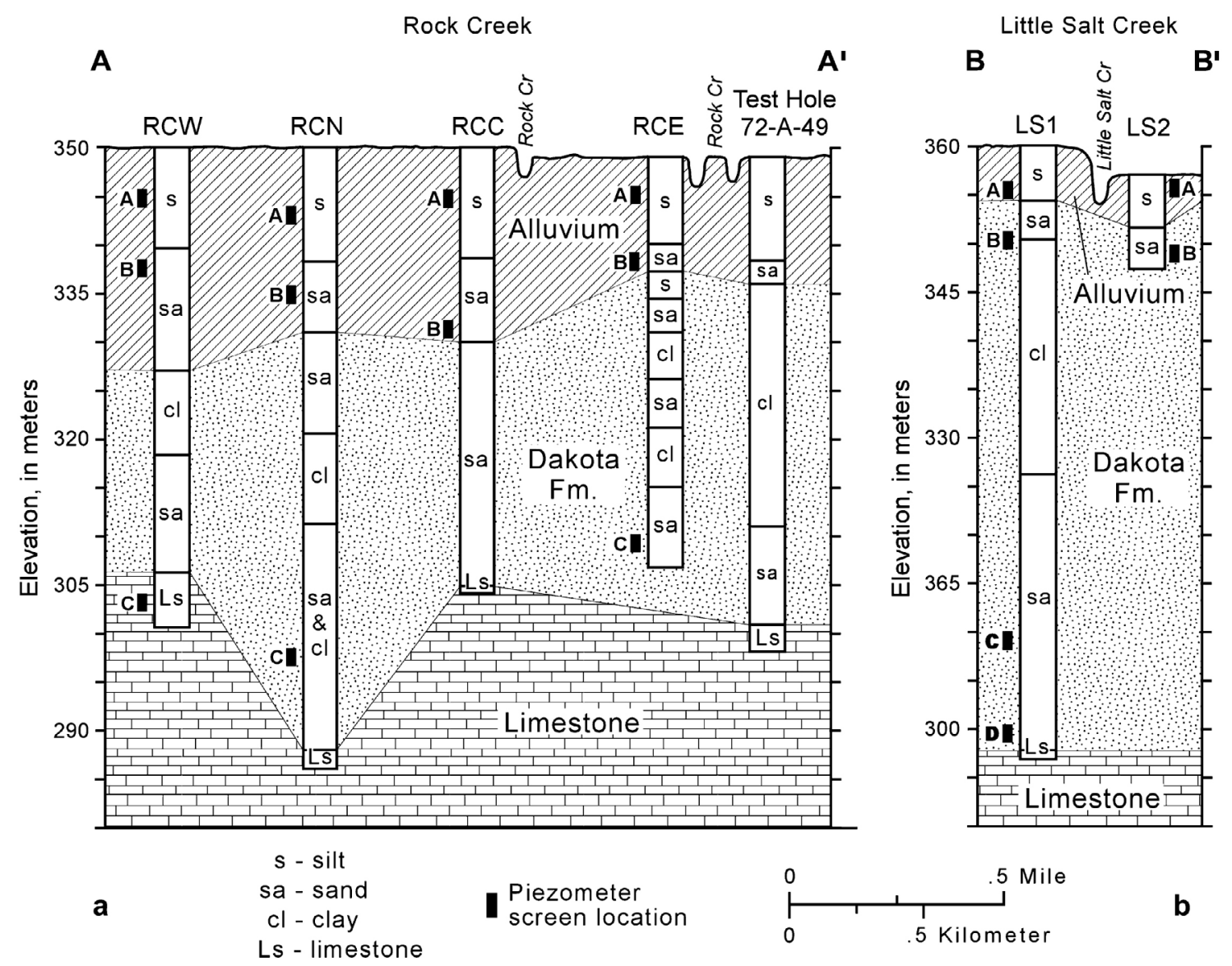

Figure 6. Geologic cross-sections of the (a) RC and (b) LSC sites. Monitoring well screen locations are also indicated.

the study period. Hydraulic gradient reversals occur during the spring months in both 2001 and 2002 at site RCE. This is likely caused by increased levels of discharge in the adjacent stream from spring runoff temporarily creating downward flow to the aquifer as the water percolates downward from the stream and nearby floodplain (Figure 5). Hydraulic gradients in the remaining wells remain upward, but do decrease in magnitude over the winter months and during individual storm recharge events.

\section{Ion chemistry}

Dissolved ion concentrations for all sampled ground water are presented in Table 1. RC ground water samples have elevated TDS values characteristic of brackish water (1000 to $10,000 \mathrm{mg} / \mathrm{L})$. LSC ground water has much higher TDS values (with the exception of the shallow well LSC1-B) just inside the range of saline water $(10,000$ to $100,000 \mathrm{mg} / \mathrm{L})$.

With the exception of LSC1-B, which has bicarbonate as its dominant anion, ground water from both the RC and LSC sites can be classified as sodium chloride (NaCl) water (Back 1966; Back and Hanshaw 1970, 1971). Sodium concentrations at the LSC site, expressed as meq/L, are approximately equal to those of chloride, suggesting halite dissolution as the primary source of these ions. At the $\mathrm{RC}$ site, however, there is an excess of sodium in addition to that associated with halite dissolution. This indicates another sodium mineral source, or perhaps ion exchange. At the RC site, calcium concentrations are approximately the same as bicarbonate, indicative of calcite dissolution. Magnesium concentrations are also high in the water but it is unclear if these result from the dissolution of dolomite, epsomite, hexahydrite, or some other magnesium-bearing mineral.

Elevated sulfate concentrations in the water result from either the dissolution of gypsum/anhydrite, hexahydrite/ epsomite, or pyrite oxidation (though dissolved iron concentrations are low) during the ground water's evolution. However, given the current chemical data, it cannot be resolved as to which of these processes is dominant. While the Dakota Formation does contain pyrite, it is not known to contain large evaporite deposits. Unpublished sulfur isotope data from Dakota ground water in northeastern Nebraska indicate evaporite as the source in older, deeper water and terrestrial sulfide oxidation in shallow, younger water. The presence of tiny gas bubbles in the water and a noticeable smell of "rotten eggs" at several of the deeper wells may indicate that sulfate reduction is also taking place within the lower portions of the Dakota Aquifer, but this has not been verified analytically.

Generally speaking, the concentrations of the various dissolved ion concentrations are roughly the same in the RC wells regardless of location or depth. Ground water from the LSC wells, however, shows increasing ion concentrations with depth for all of the major ions (note that the well screen depths are greater at the LSC site). 

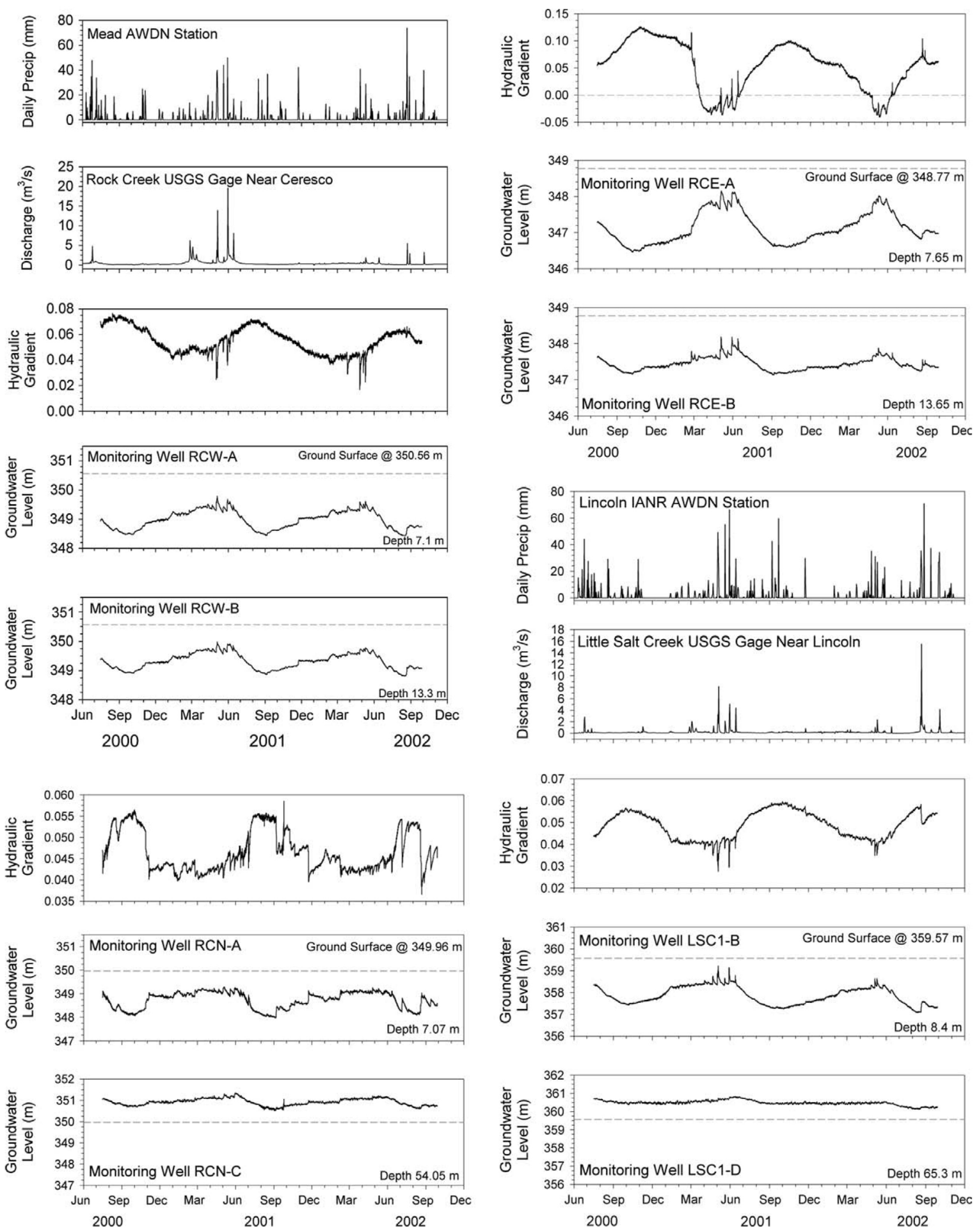

Figure 7. Hydrographs of study wells. The dashed lines on each hydrograph represent the ground surface elevation at each monitoring well location. Hydraulic gradient is vertical and is calculated between the two plotted monitoring wells at each site.

\section{Stable oxygen, hydrogen, and carbon isotopes}

The $\delta^{18} \mathrm{O}$ and $\delta^{2} \mathrm{H}$ values of global precipitation generally plot close to a straight line, called the global meteoric water line, and thus, a plot of $\delta^{18} \mathrm{O}$ vs $\delta^{2} \mathrm{H}$ can be used to determine probable water sources, identify the effects of evaporation, and examine mixing relationships between water having different stable isotope ratios (Craig 1961). In some areas where data are available, local water lines can be used to more accurately represent local precipitation isotope patterns. For this study, the local water line established in nearby Mead, Nebraska (Figure 2) by Harvey (2001) was used to represent precipitation falling at both study sites. 
Table 1. Ground Water Chemistry Data

\begin{tabular}{|c|c|c|c|c|c|c|c|c|c|c|c|c|c|c|c|}
\hline \multirow[b]{2}{*}{ Well } & \multirow[b]{2}{*}{$\mathrm{T}\left({ }^{\circ} \mathrm{C}\right)$} & \multirow[b]{2}{*}{$\mathrm{pH}$} & \multicolumn{7}{|c|}{ Concentrations (meq/L) } & \multicolumn{6}{|c|}{ Concentrations (mg/L) } \\
\hline & & & $\mathrm{Na}$ & K & $\mathrm{Ca}$ & $\mathrm{Mg}$ & $\mathrm{Cl}$ & $\mathrm{HCO}_{3}$ & $\mathrm{SO}_{4}$ & $\mathrm{Fe}$ & $\mathrm{Mn}$ & $\mathrm{Sr}$ & $\mathrm{NO}_{3}$ & $\mathrm{PO}_{4}$ & $\mathrm{TDS}^{1}$ \\
\hline LSC1-B & 15 & 7.05 & 6.57 & 0.23 & 4.57 & 9.14 & 3.02 & 9.42 & 8.99 & 0.1 & 1.1 & 0 & 0.5 & 2.1 & 1283 \\
\hline LSC1-D & 14 & 7.50 & 220.7 & 1.07 & 8.44 & 16.89 & 257.1 & 9.78 & 38.43 & 0.2 & 0.1 & 4 & 0.3 & - & 16808 \\
\hline RCC-B & 14 & 7.03 & 96.6 & 0.51 & 6.36 & 12.73 & 78.6 & 6.52 & 18.06 & 0.1 & 0.1 & 3 & 0.5 & - & 6576 \\
\hline RCE-B & 14 & 7.10 & 90.3 & 0.50 & 7.21 & 14.41 & 82.4 & 6.40 & 18.53 & 0.3 & 0.1 & 3 & 0.5 & - & 6654 \\
\hline RCW-A & 13 & 7.28 & 96.4 & 0.57 & 5.78 & 11.57 & 81.6 & 6.52 & 17.70 & 0.2 & 0.2 & 2 & 1.9 & - & 6692 \\
\hline RCW-B & 14 & 7.24 & 99.1 & 0.54 & 5.85 & 11.70 & 84.1 & 6.46 & 18.68 & 0.8 & 0.2 & 2 & 0.7 & - & 6901 \\
\hline RCW-C & 15 & 7.22 & 93.9 & 0.57 & 6.20 & 12.40 & 86.5 & 6.73 & 20.19 & 0.2 & 0.2 & 2 & 0.5 & & 6983 \\
\hline
\end{tabular}

${ }^{1}$ Computed as the sum of ion concentrations with bicarbonate converted to equivalent carbonate (Drever 1997).

Study ground water $\delta^{18} \mathrm{O}$ and $\delta^{2} \mathrm{H}$ values (Table 2) are plotted in Figure 8. The local Mead (Harvey 2001) and global (Craig 1961) meteoric water lines are also plotted for comparison. All values plot below the local and global water lines. This suggests that the water has either been impacted by some physical or chemical process such as evaporation or water-rock interaction since they originally fell as precipitation, or that they were recharged under different climatic conditions than are present today in eastern $\mathrm{Ne}-$ braska. (i.e., they fall along another local water line).

Figure 8 also shows that the ground water falls into two distinctive groups that are site dependent. Sample LSC1-B has a value similar to the yearly average $\delta^{18} \mathrm{O}$ and $\delta^{2} \mathrm{H}$ values for modern precipitation in the area (around $-7 \%$ o to $-8 \%$ and $-48 \%$ o to $-53 \%$, respectively [Harvey 2001]). This suggests that shallow ground water is meteoric in origin and has been recharged under climatic conditions similar to those currently found across the study area. The remaining water, however, plots around $-13 \%$ o to $-14 \%$ o $\left(\delta^{18} \mathrm{O}\right)$ and $-100 \%$ o to $-110 \%$ o $\left(\delta^{2} \mathrm{H}\right)$.

The ground water $\delta^{13} \mathrm{C}_{\mathrm{DIC}}$ values (Table 2) fall into two distinct groups. Ground water from LSC1-B has a heavier value typical of ground water that has entrained soil-gas $\mathrm{CO}_{2}$ and subsequently derived their DIC from the dissolution of calcite $\left(\delta^{13} \mathrm{C} \approx 0 \%\right.$ o). The remaining ground water has much lighter $\delta^{13} C_{\text {DIC }}$ values, suggesting that the water has derived more of its dissolved carbonate from organic matter $\left(\delta^{13} \mathrm{C} \approx\right.$ $-23 \%$ o) within the aquifer rather than through the dissolution of carbonates likely during sulfate reduction. If sulfate reduction is occurring in the aquifer (see above), it would produce DIC from the breakdown of organic matter within the aquifer that would result in a lighter $\delta^{13} C_{\text {DIC }}$ value.

\section{Tritium age dating}

The significant difference in tritium concentrations between prebomb precipitation (before 1952) and postbomb precipitation (after 1952), and the significant increase in tritium levels in 1963 precipitation, allow tritium to be used as a natural tracer (Clark and Fritz 1997). Tritium levels in precipitation were monitored at the International Atomic Energy Agency (IAEA) monitoring station in Lincoln, Nebraska, until 1986 (IAEA 1992). At that time, atmospheric tritium levels were approximately 14 TU. Precipitation in eastern Nebraska has similar values ranging from 10 to 30 TU (F. E. Harvey, unpublished data).

Table 2. Ground Water Isotope Data

\begin{tabular}{|c|c|c|c|c|c|c|c|}
\hline Well & $\begin{array}{c}\delta^{18} \mathrm{O} \\
(\% \text { VSMOW) }\end{array}$ & $\begin{array}{c}\delta^{2} \mathrm{H} \\
(\% \text { VSMOW) }\end{array}$ & $\begin{array}{c}\delta^{13} \mathrm{C}_{\mathrm{DIC}} \\
(\% \text { VPDB })\end{array}$ & $\begin{array}{l}{ }^{87} \mathrm{Sr} /{ }^{86} \mathrm{Sr} \\
\text { (NIST 987) }\end{array}$ & ${ }^{3} \mathrm{H}(\mathrm{TU})$ & $\begin{array}{l}\text { Uncorrected } \\
{ }^{14} \mathrm{C}(\mathrm{PMC})\end{array}$ & $\begin{array}{c}\text { Estimated } \\
{ }^{14} \mathrm{C} \text { Age }(\mathrm{ybp})^{1}\end{array}$ \\
\hline LSC1-B & -7.6 & -57 & -8.51 & 0.70893 & $5.0 \pm 0.6$ & $97.99 \pm 0.67$ & Modern \\
\hline LSC1-D & -13.3 & -104 & -14.64 & 0.70891 & $<0.8 \pm 0.5$ & $0.75 \pm 0.06$ & 36,716 \\
\hline RCC-B & -13.7 & -109 & -14.03 & 0.70973 & $<0.8 \pm 0.5$ & $5.02 \pm 0.07$ & 20,646 \\
\hline RCE-B & -13.4 & -106 & -13.47 & 0.70978 & $<0.8 \pm 0.5$ & $8.26 \pm 0.09$ & 16,193 \\
\hline RCN-C & -14.1 & -108 & -14.90 & 0.70970 & $<0.8 \pm 0.5$ & $2.51 \pm 0.09$ & 26,875 \\
\hline RCW-A & -13.8 & -110 & -14.11 & 0.70973 & $<0.8 \pm 0.4$ & $3.44 \pm 0.07$ & 23,815 \\
\hline RCW-B & -14.0 & -111 & -14.22 & 0.70972 & $<0.8 \pm 0.4$ & $3.08 \pm 0.08$ & 24,798 \\
\hline RCW-C & -13.7 & -111 & -14.49 & 0.70983 & $<0.8 \pm 0.5$ & $3.08 \pm 0.07$ & 24,952 \\
\hline
\end{tabular}

\footnotetext{
${ }^{1}$ Age estimates computed using the decay equation and a correction factor q calculated using the $\delta^{13} \mathrm{C}$ correction model.
} 


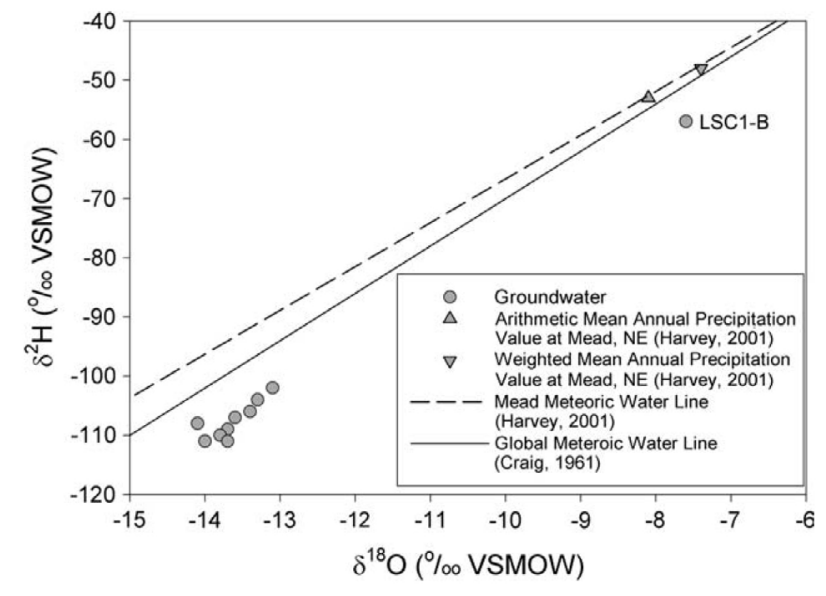

Figure 8. $\delta^{18} \mathrm{O}$ vs. $\delta^{2} \mathrm{H}$ plot for study ground water.

Tritium was used to determine the recharge age of ground water within the saline wetlands. Generally, investigators have concluded that water containing measurable tritium concentrations $(0.8 \pm 0.5 \mathrm{TU}$ for the enriched method used in this study) have been recharged since the early 1960s (Clark and Fritz 1997). Water that does not have measurable tritium concentrations $(\leq 0.8 \pm 0.5 \mathrm{TU})$ likely were recharged prior to the 1960s.

Tritium concentrations within the ground water from both sites are presented in Table 2. Tritium was detected only in LSC1-B at a concentration of $5.0 \pm 0.6 \mathrm{TU}$. This value is consistent with those of modern precipitation and likely reflects mixing of older slightly saline ground water in the upper layers of the Dakota Formation with younger downward percolating rain water which is recharging the aquifer. This interpretation is consistent with the dissolved concentrations of the major ions, which are greatly diluted as compared to water from deeper in the aquifer and with the stable oxygen and hydrogen isotope data (see previous discussion), which have a signature of modern meteoric water. The remaining ground water has concentrations below the detection limit, indicating that their age of recharge is prior to the mid-1960s.

\section{Carbon-14 age dating}

Dating ground water by ${ }^{14} \mathrm{C}$ was first proposed by Munnich (1957), where the determined ground water "age" refers to elapsed time since the water infiltrated deep enough into the saturated zone to become isolated from atmospheric $\mathrm{CO}_{2}$. Dissolution of carbonates along ground water flowpaths can impact the measured age, and thus a correction is needed to account for the addition of dead carbon. Clark and Fritz (1997) review several different methods for correcting ${ }^{14} \mathrm{C}$ ages, depending on the mineralogy and geochemical evolution of the aquifer being samples. For this study, dilution factors, $q$, were computed for the ${ }^{14} \mathrm{C}$ ages, using the chemical bass-balance, $\delta^{13} \mathrm{C}$ mixing, and matrix exchange models (Clark and Fritz 1997), all of which gave similar results. Thus, the $\delta^{13} \mathrm{C}$ mixing correction method (Pearson 1965; Pearson and Hanshaw 1970) was used for correcting the data presented here as it accounts for the amount of "dead" carbon added by both carbonate dissolution and sulfate reduction within the aquifer (see previous comments).

Table 2 lists the stable carbon-13 and carbon-14 dating results. Carbon-14 results are presented as uncorrected ${ }^{14} \mathrm{C}$ PMC values and as estimated recharge ages in ybp. The data indicate that ground water at the RC site was recharged between 16,074 and 24,952 ybp. The shallow ground water sampled from LSC1-B is modern in age (as previously indicated by the tritium dating). Deeper ground water at the LSC site has recharge ages that are slightly older than those at the RC site $(34,672$ to 36,716 ybp). This difference in ages suggests that the water has migrated from their recharge zone along different flowpaths or at different flow rates.

\section{Strontium isotopes}

Ground water acquires dissolved Sr during recharge and along its flowpath as it interacts with Sr-bearing minerals within the aquifer, and therefore the Sr isotopic composition of ground water records an integrated signal of water-rock interaction along the flowpath and can be used as a dynamic tracer to constrain subsurface flow patterns (Clark and Fritz 1997).

In this study, $\mathrm{Sr}$ isotopes were used to further document and constrain the history of ground water flow within the Dakota Formation at a more regional scale. Strontium isotope data were compiled as part of a larger, more regionally extensive study of ground water flow within the Great Plains (Dakota) Aquifer. The complete strontium data set is discussed by Gosselin et al. (2004). The smaller saline wetland data set presented here (Table 2) serves to show only that the ground water at the two study sites have had distinctly different water-rock interaction histories. In the context of the regional data from the Dakota Formation in Nebraska and Kansas, the values suggest that water discharging in the saline wetlands did not derive its dissolved strontium concentrations from minerals within the Dakota Formation, which when leached with water produced an average value of 0.709960 , but more likely from the underlying Pennsylvanian rocks, which yielded an average value of 0.708878 (see detailed discussion in Gosselin et al. [2004]).

\section{Discussion}

Using the physical and chemical results of this study, a basic conceptual model of ground water flow beneath and to the saline wetlands was constructed and it is depicted in Figure 9. At most locations within the stream valleys, higher TDS, saline ground water flows to the surface under artesian conditions and discharges to the wetlands and/or streams where the potentiometric surface lies above the land surface. Locally, gradients may be downward at times (RCE) due to the impact of higher stream flows and or weirs creating back water ponding. Prior to settlement, stream channelization, and the decline of stream and ground water levels, this saline discharge at the surface was seen throughout the region and across most of the alluvial stream valleys. 


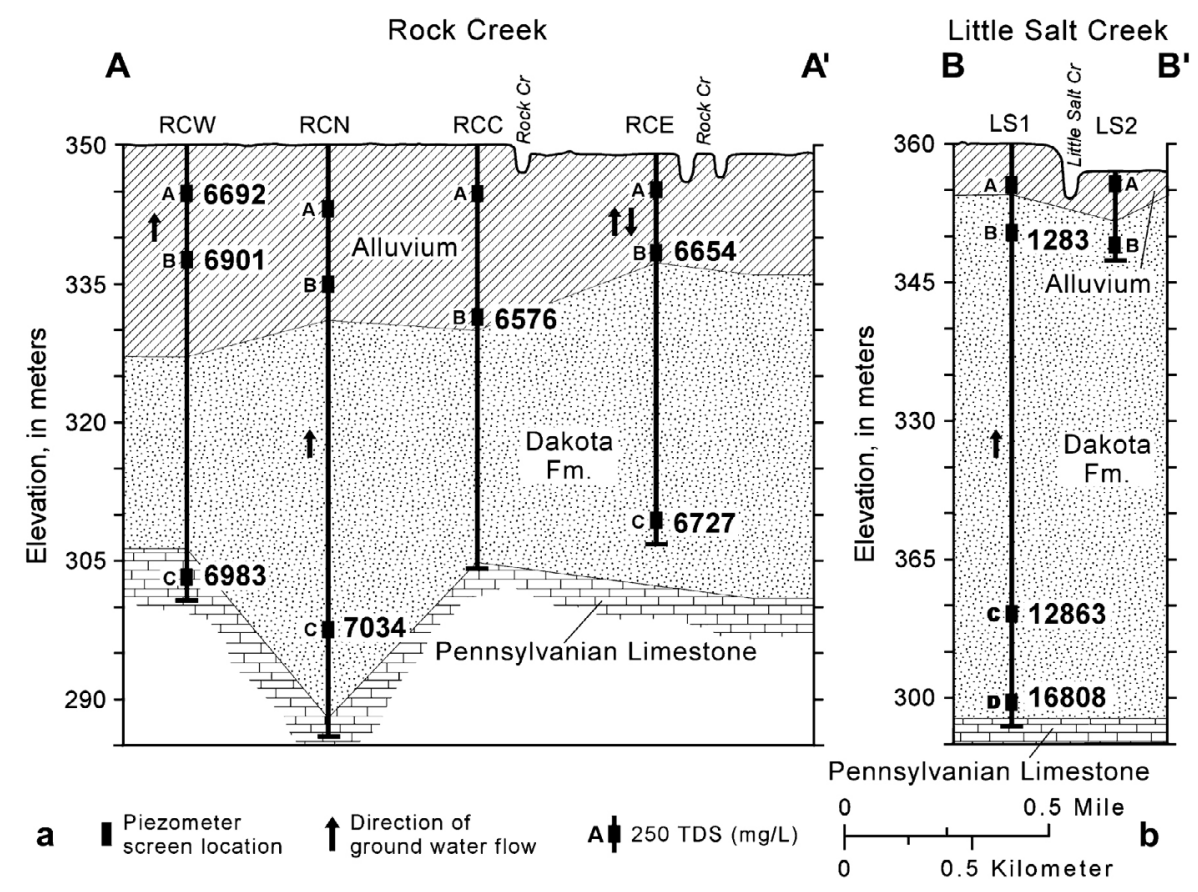

Figure 9. Conceptual model of ground water flow and ion transport beneath the saline wetland.

However, ground water level monitoring during the course of this study indicates that upwelling ground water was not reaching the surface of the wetlands at the RC and LSC sites and was present only in the upper few meters of the soil column during the spring months when levels were at their maximum due to winter snowmelt and spring rainstorms. This apparent decline in the maximum extent of upward ground water level rise may result from the short-term drought conditions of 2000, or the decline may result from the longer term incision of local streams, which has subsequently lowered the water table across the alluvial stream valleys. This study did not observe any saline ground water seeps, springs, or surface discharges at either of the two sites studied that resulted from upwelling saline ground water; though they had been observed at these sites in the past and are currently seen elsewhere within the region where surface topography intersects the water table.

Seepage can be seen locally along the banks of the nearby streams, but conductivity measurements show that this water is less saline than the underlying ground water and results not from upward migration of water but rather from the downward percolation and subsequent migration of rain water along a buried presettlement soil layer to the stream banks. It should be pointed out that actual ground water seepage measurements have not yet been made in the streams to determine ground water's contribution. This lack of saline seepage at the surface suggests the possibility that the dissolved salts (for example, sodium, chloride, potassium) critical to the sustenance of the unique indigenous saline ecosystems may no longer be deposited within the upper soil layers. This observed change in the hydrodynamics of the wetlands might account for the noted decrease in the number and size of salt flats scattered across these wetlands in recent years, and the replacement of saline wetland vege- tation with more fresh water-tolerant plants such as cattails (Typha spp.) and reed canary grass (Phalaris arundinacea), for example (T. LaGrange, 2007, personal communication).

The position of the water table recorded in study well hydrographs and visual observations by the first author at both sites suggest that the salt flats observed in drier years may not necessarily be created by the direct evaporation at or near the surface of saline soil-pore water derived from older upwelling saline ground water as previously thought, but rather these flats may now be created by the evaporation of modern surface water derived from precipitation or runoff that has subsequently redissolved salts from atop the surface or from within the near surface soils - salts that were previously carried into and deposited within the upper layers of the alluvium by older upwelling ground water during wetter or possibly under presettlement hydrologic conditions (i.e., when regional water tables and stream levels were higher).

If this redissolution is occurring at the surface, current wetland management efforts to retain and pond surface water believed to be saline and originating as overland flow from adjacent Dakota seeps (Figure 3) might actually be detrimental to the saline wetlands if they are not actually capturing saline water. Captured fresh water, ponded on the surface, above the water table will induce downward infiltration into and through the underlying soil of water that has dissolved surface salts or salts within the upper soil layers, transporting the salts downward away from the wetland ecosystem. Over time, since the salts are no longer replaced by upwelling saline ground water, this downward rinsing will serve to gradually deplete surface salt deposits and reduce the salinity of both pore water and surface water. This too would result in a reduction of slat flat areas and further encroachment by fresh water vegetation. 
The mineral source for the dissolved "salt" found in the ground water discharging at the surface of the saline wetlands has been sought after for over 100 years. For example, the economic prospect of commercial salt manufacturing prompted the drilling of a 751-m-deep well in December of 1885 to try to locate a source. The well produced brine but failed to locate buried salt deposits within the underlying formations (McKee 2003). Subsequent attempts also failed, though a deep salt source is still believed to exist by many scientists working within the wetlands. The chemical and isotopic results of this study indicate that the salt source lies not within the Dakota Formation but more likely within the underlying Pennsylvania or Permian formations, or formations farther along the upflow path to the west. Strontium isotope data suggest that the water upwelling within the saline wetlands has been transported over much more extensive regional distances rather than having been recharged into the Dakota Aquifer locally (Gosselin et al. 2004, 2001). Ground water ${ }^{14} \mathrm{C}$ ages also suggest more regionally extensive migration of the ground water as the source, rather than local, modern recharge directly to the Dakota Aquifer beneath the wetlands.

The presence of older, isotopically light ground water discharging to the wetlands from the underlying Dakota Aquifer suggests several water origin possibilities, all of which need to occur under either cooler climate conditions or at higher altitudes to account for the more depleted values. Stotler (2000) presented several origin options for ground water with similarly isotopically light oxygen and deuterium isotope values collected from the Dakota Aquifer in northeastern Nebraska. These include that (1) water is meteoric in origin, but was recharged locally during the Pleistocene Epoch when temperatures were much colder across the region; (2) water represents glacial melt water, recharged to the Dakota Formation in eastern Nebraska during the Pleistocene Epoch; or (3) water has migrated over a more regional flowpaths from a recharge zone at a much higher altitude farther to the west. A more rigorous discussion of the likelihood of each of these scenarios is forthcoming and will not be presented here except to note that, given the known geology and hydrology (Figure 4) of the Dakota Aquifer, its inorganic hydrogeochemistry (Table 1, Gosselin et al. 2001; Stotler 2000), and the isotopic data presented here (Table 2) and acquired for Dakota ground water across eastern Nebraska (Gosselin et al. 2004, 2001; Stotler 2000; Harvey, unpublished data), the fourth hypothesis is the simplest and most likely - specifically that water recharged outcrops of the Dakota Aquifer or other underlying formations farther to the west (possibly even along the Front Range of the Rocky Mountains in Colorado) and subsequently migrated westward along regional flowpaths (Figure 4) to discharge in eastern Nebraska's Salt Creek Valley.

The combined results imply that the present-day saline wetland ecosystems are dependent upon a regional scale hydrogeologic flow system (Tóth 1962, 1963) having travel times on the order of thousands to tens of thousands of years rather than tens to hundreds. Also, this regional flow system may not be replenished indefinitely (the extent of the parcel of saline water at depth is presently unknown) since recharge is neither local nor recent. Thus, while future hydrologic conditions cannot be predicted with certainty as they are dependent on regional scale geochemical transport processes and not merely local recharge and salt dissolution within the alluvial soils, saline wetland managers should recognize that there is a need to manage not only the local flow system immediately beneath and adjacent to the alluvial stream valleys and the wetlands themselves but also the more regional system, including the surrounding upland areas and recharge areas farther to the west, wherever and whenever possible.

\section{Conclusions}

This study concluded that the saline conditions present within the eastern Nebraska saline wetlands result from the upwelling of saline ground water through the underlying Dakota Aquifer having their origins in the deeper, underlying formations of Pennsylvanian and Permian age. Saline ground water has migrated for thousands to tens of thousands of years, along regional scale flowpaths from cooler climate, or higher altitude recharge zones in the west to the present-day discharge zones along the saline streams of Rock, Little Salt, and Salt creeks in Lancaster and Saunders counties.

As with other threatened or endangered wetland ecosystems, the endemic species living within Nebraska's saline wetlands have evolved under a unique set of hydrologic conditions, and thus have a more narrow range of adaptive tolerance to changes in salinity than other more common fresh water wetland species. Thus, even seemingly small changes in the local hydrodynamics of the ecosystem - the 1- to 2-m decline in water table below the salt flats due to channel incision (or drought) that results in the loss of saline water transport to the surface, for example-could have disastrous results even to moving these species to or past the proverbial "point of no return." Therefore, the fragility of such systems demands an even greater understanding of the sometimes subtle interrelationships between geology, hydrology, water chemistry, and biology than in less imperiled systems where adaptation is more likely.

Furthermore, generally speaking, when dealing with saline ground water discharge-dependent ecosystems, this study indicates that wetland managers and planners must expand their management and protection policies and plans to include areas outside of the immediate surface location of the visible ecosystem to include upland areas where recharge occurs, and adjacent areas where lateral transport of ground water might play a vital role in the hydrologic mixing dynamics of the wetlands. (This same conclusion could also be applied to regionally driven ground water-fed fresh water systems where the long-distance transport of nutrients might be critical to the more localized ecosystem.)

Where ecosystems are dependent on not only the discharge of the ground water but also the discharge of the dissolved salts within the ground water, as is the case with the saline wetlands, greater understanding of the mixing dynamics between surface fresh and deeper saline water is critical, such that commonly used surface management 
practices such as berming and ponding aimed at restoration of wetland hydrology and preservation of saline plant and animal communities do not tragically result instead in further degradation of the saline wetland flora and fauna by alteration of the critical wetland hydrochemistry via the dilution and removal of the vital salts.

\section{Acknowledgments}

The authors wish to thank Ted LaGrange, Wetland Program Manager, NGPC, and Chris Helzer, The Nature Conservancy, for their assistance with field site selection, access, and coordination. Bob Drimmie is thanked for his insights during discussions with the first author. Olsson Environmental provided historical and restoration information for the LSC site. Randy Stotler assisted the principal author with transducer setup, installation, and monitoring, well elevation surveying, and water chemistry sampling. Kelli Warren, Carol Rogers, and Brian Deitz also assisted with the fieldwork. Amy Zlotsky, Kyle Hoagland, and Randy Stutheit provided information on wetland ecology, and Bill Zanner assisted with soil classification and soil chemistry. We thank the various Nebraska Conservation and Survey drilling crews for installing the monitoring wells, and cartographers Dee Ebbeka and Ann Mack for drafting several of the figures. Funding for this project was provided by the U.S. Environmental Protection Agency (USEPA), region 7-Grant Project \#997452-01-2. Thanks to Raju Karkarlapudi, Ann Jaccobs, and Tom Taylor (USEPA) for their assistance with administering this grant. Finally, we offer special thanks to Ground Water editor Mary Anderson, reviewers Don Siegel and Carl Mendoza, and the anonymous reviewer and associate editor for Ground Water whose comments greatly improved the quality of this manuscript.

\section{References}

Ayers, J. F. 1995. Rock creek watershed: A preliminary hydrogeologic investigation, interim report to water resource planning. Lincoln, Nebraska: U.S. Soil Conservation Service.

Back, W. 1966. Hydrochemcial facies and ground-water flow patterns in the northern part of Atlantic Coastal Plain. USGS Professional Paper 498-A. Reston, Virginia: USGS.

Back, W., B. B. Hanshaw. 1971. Geochemical interpretations of groundwater flow systems. Water Resources Bulletin 7, no. 5: 1008-1016.

Back, W., B. B. Hanshaw. 1970. Comparison of chemical hydrogeology of the carbonate peninsulas of Florida and Yucatan. Journal of Hydrology 10, no. 4: 330-368.

Brock, M. A., R. J. Shiel. 1983. The composition of aquatic communities in saline wetlands in Western Australia. Hydrobiologia 105, no. 1: 77-84.

Burlington Northern Railroad Company. 1997. Final Wetland Mitigation Bank Plan For Burlington Northern Railroad Company's Hobson Yard Upgrade and Expansion Project, Lincoln, Nebraska. Prepared by EA Engineering, Science and Technology. Lincoln, Nebraska.

Clark, I., P. Fritz. 1997. Environmental Isotopes in Hydrogeology. Boca Raton, Florida: Lewis Publishers, CRC Press.
Clausen, M., M. Fritz, G. Steinauer. 1989. The Nebraska natural heritage program a two year progress report. Lincoln, Nebraska: Nebraska Game and Parks Commission.

Coleman, M. L., T.J. Shepherd, J. J. Durham, J. E. Rouse, G. R. Moore 1982. Reduction of water with zinc for hydrogen isotope analysis. Analytical Chemistry 54, 993-995.

Cooper, H. H. Jr., F. A. Kohout, H. R. Henry, R. E. Glover. 1964. Sea water in coastal aquifers. USGS Water-Supply Paper 1613C. Reston, Virginia: USGS.

Craig, H. 1961. Isotopic variations in meteoric waters. Science 133, 1702.

Department of the Interior - Fish and Wildlife Service (DOE-FWS). 2005. Endangered and threatened wildlife and plants; determination of endangered status for the salt creek tiger beetle (Cicindela nevadica lincolniana). 50 CFR Part 17, RIN 1018-AJ13, Federal Register/Vol. 70, No. 193/, October 6, 2005/Rules and Regulations, 58335.

Drever, J. I. 1997. The Geochemistry of Natural Waters: Surface and Groundwater Environments, 3rd ed. Upper Saddle River, NJ: Prentice Hall, 436 p.

Eamus, D., R. Froend. 2006. Groundwater-dependent ecosystems: the where, what and why of GDEs. Australian Journal of Botany 54, no. 2: 91-96.

Eckhardt, G. 2006. The Edwards Aquifer website. http://www. edwardsaquifer.net/ (accessed November 11, 2006).

Epstein, S., T. Mayeda. 1953. Variations of ${ }^{18} \mathrm{O}$ content of waters from natural sources. Geochimica et Cosmochimica Acta 4, no. 5: 213-224.

Farrar, J., R. Gersib. 1991. Nebraska Salt Marshes: Last of the Least. Lincoln: Nebraska Game and Parks Commission.

Gosselin, D. C., F. E. Harvey, C. Frost, R. Stotler, P. A. Macfarlane. 2004. Strontium isotope geochemistry of groundwater in the central part of the Dakota (Great Plains) Aquifer, U.S.A. Applied Geochemistry 19, 359-377.

Gosselin, D. C., F. E. Harvey, C. D. Frost. 2001. Geochemical evolution of ground water in the Great Plains (Dakota) Aquifer of Nebraska: Implications for the management of a regional aquifer system. Ground Water 39, no. 1: 98-108.

Gupta, S. K., H. A. Polach. 1985. Radiocarbon Dating Practices at ANU: Handbook, Radiocarbon Laboratory, Research School of Pacific Studies. Canberra, Australia: Australian National University.

Harvey, F. E. 2001. Use of NADP archive samples to determine the isotope composition of precipitation: Characterizing the meteoric input function for use in ground water studies. Ground Water 39, no. 3: 380-390.

Harvey, F. E., J. B. Swinehart, T. M. Kurtz. 2007. Ground water sustenance of Nebraska's unique Sand Hills peatland fen ecosystems. Ground Water 45, no. 2: 218-234.

Hatton, T., R. Evans. 1998. Dependence of ecosystems on groundwater and its significance to Australia. Occasional Paper No. 12/98. Canberra, Australia: Land and Water Resources Research and Development Corporation, CSIRO.

Hayashi, M., D. O. Rosenberry. 2002. Effects of ground water exchange on the hydrology and ecology of surface water. Ground Water 40, no. 3: 309-316.

Hayden, F. V. 1872. Final Report of the United States Geological Survey of Nebraska and Portions of the Adjacent Territories. Washington, DC: Government Printing Office.

Helgeson, J. O., D. G. Jorgensen, R. B. Leonard, D. C. Signor. 1984. Regional study of the Dakota Aquifer (Darton's Dakota revisited). In Geohydrology of the Dakota Aquifer, Proc. C.V. Theis Conference on Geohydrology. ed. D. G. Jorgensen \& D. C. Signor, 69-76. Dublin, Ohio: National Water Well Association. 
Helgeson, J. O., D. G. Jorgensen, R. B. Leonard, D. C. Signor. 1982. Regional study of the Dakota Aquifer (Darton's Dakota revisited). Ground Water 20, no. 4: 410-414.

International Atomic Energy Agency (IAEA). 1992. Statistical treatment of data on environmental isotopes in precipitation. Technical Reports Series No. 331. Vienna, Austria: IAEA.

Jagtap, T. G., S. H. Bhosale, V. L. Nagle. 2002. Ecological observations on major Salicornia beds from highly saline coastal wetlands of India. Wetlands 22, no. 3: 443-450.

Joeckel, R. M., B. A. Clement. 1999. Surface Features of the Salt Basin of Lancaster County. Lincoln, Nebraska: Catena.

Jorgensen, D. G., J. O. Helgeson, J. L. Imes. 1993. Regional aquifers in Kansas, Nebraska, and parts of Arkansas, Colorado, Missouri, New Mexico, Oklahoma, south Dakota, Texas, and Wyoming-Geohydrologic framework. USGS Professional Paper 1414-B. Reston, Virginia: USGS.

Kaul, R. B. 1975. Vegetation of Nebraska (circa 1850). Map. Lincoln: University of Nebraska-Lincoln, Conservation and Survey Division.

Leonard, R. B., D. C. Signor, D. G. Jorgensen, J. O. Helegesen. 1984. Geohydrology and hydrochemistry of the Dakota Aquifer, central United States. In Geohydrology of the Dakota Aquifer, Proceedings of the C.V. Theis Conference on Geohydrology, ed. D.G. Jorgensen \& D. C. Signor, 229-237. Dublin, Ohio: National Water Well Association.

Longley, G. 2006. The Edwards Aquifer and its unique ecosystem-Potential threats from groundwater management. Geological Society of America Annual Meeting, Philadelphia, Pennsylvania: October 22-25. Abstracts With Programs. 38, no. 7: 327.

Maher, H. D. Jr., G. F. Englemann, R. D. Shuster. 2003. Roadside Geology of Nebraska. Missoula, Montana: Mountain Press Publishing Company.

McKee, J. 2003. History resurfaces as local lake is drained. Lincoln Journal Star. September 14, 2C.

Mitsch, W. J., J. G. Gosselink. 2000. Wetlands. New York: John Wiley \& Sons Inc.

Munnich, K. O. 1957. Messung des 14C-Gehaltes von hartem grundwasser. Naturwissenschaften 44, no. 2: 32-34.

National Research Council. 2005. Endangered and Threatened Species of the Platte River. Washington, DC: National Academies Press.

Nilius, R., G. Graening. 2000. Ozark underworld. Endangered Species Bulletin 25, no. 5: 14-17.

Pavek, D. 2002. Endemic amphipods in our nation's capital. Endangered Species Bulletin 27, no. 1: 8-9.

Pearson, F. J. Jr 1965. Use of ${ }^{13} \mathrm{C} /{ }^{12} \mathrm{C}$ ratios to correct radiocarbon ages of materials initially diluted by limestone. Proceedings of the Sixth International Conference on Radiocarbon Dating, 357366. Pullman, Washington.

Pearson, F. J. Jr. B. B. Hanshaw. 1970. Sources of dissolved carbonate species in groundwater and their effects of carbon-14 dating. In Isotope Hydrology, Proceedings Symposium of the International Atomic Energy Agency and UNESCO, Vienna. Vienna, Austria: International Atomic Energy Agency, 271-286.

Pennings, S. C., M. B. Grant, M. D. Bertness. 2005. Plant zonation in low-latitude salt marshes: Disentangling the roles of flooding, salinity and competition. Journal of Ecology 93, no. 1: 159-167.

Rus, D. L., B. J. Dietsch, A. Simon. 2003. Streambed adjustment and channel widening in eastern Nebraska. USGS Water Resources Investigations Report 03-4003. Lincoln, Nebraska: USGS.
Sánchez Navarro, J. A., P. Coloma López, A. Pérez García. 2001. Saline wetlands related to groundwater flows from low permeability tertiary formations in the Somontano area of Huesca, Spain. Hydrological Processes 15, no. 4: 633-642.

Shaw, S. P., C. G. Fredine. 1956. Wetlands of the United States - their Extent and their Value to Waterfowl and other Wildlife. Circular 39. Washington, DC: U.S. Department of the Interior,

Shirk, C. J. 1924. An Ecological study of the vegetation of an inland saline area. Ph.D. thesis, Lincoln, Nebraska: Department of Botany, University of Nebraska-Lincoln.

Smith, L. M. 2003. Playas of the Great Plains. Austin, Texas: University of Texas Press.

Stotler, R. L. 2000. Isotopic evidence for Pielstocene recharge in the Dakota Aquifer, northeast Nebraska. B.S. Thesis, School of Natural Resources, University of Nebraska-Lincoln, Lincoln, Nebraska, $72 \mathrm{p}$.

Strobel, M. L., P. J. Gerla. 1993. Hydrologic and anthropogenic influences on the occurrence of saline wetlands in the Red River of the North Valley, Northeastern, North Dakota. Prairie Ecosystems. Abstracts, Wetland Ecology, Management and Restoration, Wetland Symposium, August 9-13, Jamestown, North Dakota.

Stuiver, M., H. A. Polach. 1977. Discussion: Reporting of C-14 data. Radiocarbon 19, no. 3: 355-363.

Taylor, C. B. 1977. Tritium enrichment of environmental waters by electrolysis: Development of cathodes exhibiting high isotopic separation and precise measurement of tritium enrichment factors. Proceedings of the International Conference of Low-Radioactivity Measurements and Applications, Slovenski Pedagogicke Nakladatelstvo, Bratislava, 131-140.

Tóth, J. 1963. A theoretical analysis of groundwater flow in small drainage basins. Journal of Geophysical Research 68, no. 16: 4795-4812.

Tóth, J. 1962. A theory of groundwater motion in small drainage basins in central Alberta. Journal of Geophysical Research 67: 4375-4387.

Ungar, I. A., W. Hogan, M. McClelland. 1969. Plant communities of saline soils at Lincoln, Nebraska. American Midland Naturalist 82, no. 2: 564-577.

U.S. Department of Agriculture (USDA). 1996. Rock Creek Saline Wetland Cooperative River Basin Study, Cooperative Study with Nebraska Department of Environmental Quality, Nebraska Natural Resources Commission, Nebraska Game and Parks Commission, Lower Platte South Natural Resources District. Washington, DC: USDA.

U.S. Fish and Wildlife Service (USFWS). 2007. The endangered species program website. http://www.fws.gov/endangered/ (accessed April 2007).

U.S. Fish and Wildlife Service (USFWS). 2006. Proposed rules, Federal Register online via GPO access \{wais.access.gpo.gov\}, FR Doc 06-7375. September 12, Volume 71, Number 176, p 53800. http://www.fws.gov/policy/library/06-7375.html (accessed November 2006).

Veatch, M. D. 1969. Ground water occurrence - movement - hydrochemistry - within a complex stratigraphic framework. Jefferson County Nebraska. Ph.D. diss., Geological and Environmental Sciences. Palo Alto, California: Stanford University.

Witzke, B. J., G. A. Ludvigson. 1994. The Dakota formation in Iowa and the type area. In Perspectives on the Eastern Margin of the Cretaceous Western Interior Basin, ed. G. W. Shurr, G. A. Ludvigson, \& R. H. Hammond, 43-78. Boulder, Colorado: Geological Society of America Special Paper 287. 